\title{
Analysis of Student Difficulties and Learning Outcomes with Guided Inquiry Learning Model
}

\author{
Ratna Kumala Dewi ${ }^{1}$, Sri Wardani ${ }^{2}$ \\ ${ }^{1,2}$ Department of Chemistry Education, Graduate School Universitas Negeri Semarang, Indonesia \\ ${ }^{1}$ Corresponding email: ratnakumaladewi@students.unnes.ac.id
}

\begin{abstract}
This study aims to analyzed the guided inquiry learning model of students' chemistry learning outcomes at SMA Negeri 8 Semarang. This research method used descriptive analysis. Data analysis techniques in this study were conducted with a literature review. Data collection methods were carried out by observation, questionnaire distribution, documentation, teacher interviews, and student interviews. This research instrument consists of observation sheets, questionnaires, and interview sheets. The results of the study showed that students still had difficulty in the chemical learning material, therefore the right learning model was needed to improve student learning outcomes, one of them was by applying the guided inquiry learning model. Based on the results of the study it can be concluded that the guided inquiry learning model can help overcome student learning difficulties in chemistry learning and could improve student learning outcomes in school.
\end{abstract}

Keywords: Guided Inquiry, Descriptive Analysis

\section{Introduction}

Chemistry was a part of Natural Sciences which includes understanding concepts and chemical calculations. Chemistry was a compulsory subject in high school and included in one of the subjects in the national exam. Chemistry subjects discuss material included the composition, structure, properties, changes in energy and the accompanying material. Chemistry lessons in high school aim to enable students to understand interrelated theories, principles, concepts and laws so that they can apply their knowledge in daily life (Hunnicutt, Grushow, \& Whitnell, 2015). Chemistry was initially obtained and developed based on experiments but later developed based on theory (Jack, 2013).

The results of observations conducted at SMA Negeri 8 Semarang showed that chemistry learning was still dominated by discussion methods which it teacher-centered activities so that students became inactive. The results was low in the students learning outcomes which indicated by the average score of mid-semester repetition of class $X$ in SMA Negeri 8 Semarang at 62 while the standard value was 75 . The results of research conducted by Gumilar et al (2017) show that the low learning outcomes in chemistry learning was caused by students 'difficulties in solving problems in chemistry such as calculations and formulas so that students' learning interest is lacking. The material of chemistry lessons in senior high school contained by chemical reactions and calculations concept that were quite difficult for students to understand (Ural, 2016).

SMA Negeri 8 Semarang had applied 2013 Curriculum. The theme of the 2013 curriculum development was to produce productive, creative, innovative and affective Indonesian people through integrated attitudes, skills and knowledge (Roza, Satria, \& Siregar, 2017; Susanto, 2014). The 2013 curriculum was structured with the aim of forming students who excellent in three domains of competence, it was attitudes, skills, and knowledge (Gunawan, 2017). The chemistry teacher at SMA Negeri 8 Semarang realized that learning in using the 2013 curriculum was still lacking, especially in teaching materials. Teaching material in the 2013 curriculum was much less because it used thematic (Muth'im, 2014). Teaching materials or teacher and student handbooks only refer to the books available in the library so that student learning activities were low.

The low level of student learning activities is partly because the learning process was less attractive (Ifeoma \& Oge, 2013). The class atmosphere tends to be passive, teachers were more dominant than students. Assessment of learning outcomes could provide information to teachers 
about the progress of students in achieving learning goals through various learning activities (Setiawan, Sunarti, \& Astriani, 2016). Student learning outcomes could be improved one of them by applying learning models that are in accordance with student circumstances (Zaini, 2016).

Based on these problems, a learning model is needed that can make students active in the learning process. The learning model used by the teacher plays a role in the learning objectives to be achieved (Azizmalayeri, Mirshahjafari, Sharif, Asgari, \& Omidi, 2012). Selection of learning models must be adjusted to the conditions of students, school conditions, and learning needs (Bartos \& Lederman, 2014). One learning model that can make students active in learning was the guided inquiry model (Sukma \& Ibrahim, 2016). Research (Wardani, Nurhayati, \& Safitri, 2016) states that the guided inquiry model can improve students' understanding of concepts and learning outcomes. The guided inquiry model is student-centered learning and makes students more active in the learning process (Pedaste et al., 2015). The guided inquiry learning model allows students to systematically analyze and solve learning difficulties (Villagonzalo, 2014). The difficulty of students in studying chemistry is one of the obstacles in the learning process (Hunnicutt et al., 2015). These difficulties can be overcome by using guided inquiry learning models (Gupta, Burke, Mehta, \& Greenbowe, 2015). The purpose of this study was to analyze students' difficulties based on their learning outcomes with solutions using the guided inquiry learning model.

\section{Method}

The research method used in this research was a descriptive qualitative research method which was described and analyzed the data of the mid-semester students with qualitative explanatory sentences. This research was conducted on April 18, 2018 at SMA Negeri 8 Semarang in the even semester of 2017/2018 school year. The population of this study were all students of class $\mathrm{X}$ at SMA Negeri 8 Semarang. The sample of this study is one of class $\mathrm{X}$ in SMA Negeri 8 Semarang, namely class XE. The research instrument used in this study were a school state observation sheet, documentation, questionnaire for student responses to the learning process, teacher interview sheets, and student interview sheets. The research instrument was validated by the supervisor. In conducting observations, researchers are directly involved in data collection through interviews and documentation.

\section{Result and Discussion}

The results of observations at SMA Negeri 8 Semarang at the time of ongoing learning showed less interest and learning motivation because many did not pay attention when the teacher was teaching. Students tend to be less active so that teacher and student interactions were not going well. The chemical laboratory at SMA Negeri 8 Semarang was used as class XI due to lack of space. This caused a lack of chemical practicum activities at school. The arrangement and maintenance of chemical laboratories were not considered so that many laboratory equipments were seen which have been damaged and left alone. The use of laboratories needs to be maximized in schools, especially during lessons. The laboratory should not be used as a class so that the practicum can be carried out according to the schedule considering that the laboratory was one of the supports in chemistry learning (Gaddis \& Schoffstall, 2007). Based on the results of the interview, students understand and understand the material taught through direct practice rather than theory.

\begin{tabular}{|c|c|c|c|c|c|c|c|c|c|}
\hline \multirow{2}{*}{ Sulfipet } & \multicolumn{9}{|c|}{ Class } \\
\hline & $\mathrm{XI}$ & $X B$ & XC & (I) & $\mathrm{XE}$ & $\mathrm{NF}$ & $X 6$ & $\mathrm{SH}$ & $\mathrm{x}]$ \\
\hline Avengt & 654167 & (6):972 & 61.3889 & 61.1111 & 59.444 & 60.1389 & 63.8889 & 638899 & 62.5 \\
\hline$s^{2}$ & 233.39 & 3440128 & 276587 & 183016 & 31254 & 19:552 & 180016 & 190.159 & 240714 \\
\hline s & 152772 & 16.2469 & 16.699 & 135283 & 17.6788 & 13,913 & 135283 & 137888 & $15 j 15$ \\
\hline Score Min & 20 & 80 & D) & 35 & 211 & 35 & 25 & 35 & 85 \\
\hline Sore $\mathrm{Mla}$ & 85 & $\mathbb{B}$ & 85 & 80 & 90 & 9] & 90 & 90 & 901 \\
\hline
\end{tabular}

The results of interviews randomly with three students of grade $\mathrm{X}$ showed that students still lacked understanding of the concept of chemistry, especially in the calculation material. The teacher gave many formulas and memorization in chemistry lessons. The results of interviews with chemistry teachers at SMA Negeri 8 Semarang showed that 
teachers used the discourse and discussion learning model more often. Teachers wrote the material on the blackboard then asked students for discussion. Teachers sometimes used ppt media in teaching, but many students had not been able to understand the concept because the material taught was abstract and not practiced in the laboratory. We analyed of student learning outcomes to determine the level of difficulty experienced by students. It also aimed to describe the value of student learning outcomes before using a new learning model. The result of analyzed was students' cognitive based on observations at SMA Negeri 8 Semarang through the scores of the mid-semester students in the chemistry lessons contained in Table 1.

Table 1. Mid-Semester Results Value Data Even Grade X Students

\begin{tabular}{cccccccccc}
\hline \multirow{2}{*}{ Subject } & \multicolumn{8}{c}{ Class } \\
\cline { 2 - 9 } & $\mathrm{XA}$ & $\mathrm{XB}$ & $\mathrm{XC}$ & $\mathrm{XD}$ & $\mathrm{XE}$ & $\mathrm{XF}$ & $\mathrm{XG}$ & $\mathrm{XH}$ & $\mathrm{X}$ \\
\hline Average & 65.4167 & 60.9722 & 61.3889 & 61.1111 & 59.4444 & 60.1389 & 63.8889 & 63.8889 & 62 \\
$\mathrm{~S}^{2}$ & 233.393 & 264.028 & 276.587 & 183.016 & 312.54 & 193.552 & 183.016 & 190.159 & 240. \\
$S$ & 15.2722 & 16.2489 & 16.6309 & 13.5283 & 17.6788 & 13.9123 & 13.5283 & 13.7898 & 15. \\
Score Min & 20 & 20 & 20 & 25 & 20 & 35 & 25 & 35 & 2 \\
Score Max & 85 & 85 & 85 & 80 & 90 & 90 & 90 & 90 & 9 \\
\hline
\end{tabular}

Based on the results of the average analysis the whole class of 62 was less than the student's KKM value of 75 . The low learning outcomes of students at SMA Negeri 8 Semarang were caused by several factors. Analysis of factors influencing students' chemistry learning outcomes in SMA Negeri 8 Semarang were grouped into three main components. It were teacher, content or teaching material, and students. The interaction between the three components involved learning models, learning media, and structuring the learning environment.

The learning model applied by the teacher was not only discourse, discussions, and practice questions. Teachers could look for other learning models so that learning was not boring and students were enthusiastic in learning $(\mathrm{Ku}, \mathrm{Ho}, \mathrm{Hau}, \& \mathrm{Lai}, 2014)$. One of the learning model to improve student learning outcomes was guided inquiry learning model. The guided inquiry learning model was a series of learning activities that involve maximally all the ability of students to search and investigate systematically, critically, logically, analytically, so that students could formulate their own knowlegde with confidence (Allen, Barker, Ramsden, Academy, \& Point , 1986; Duran \& Dökme, 2016). This learning model was essentially a process of discovery or investigation (Kimberlin \& Yezierski, 2016). The main objective was to encourage students to develop thinking skills by giving questions and getting answers to students' curiosity (Suárez, Specht, Prinsen, Kalz, \& Ternier, 2018). The learning process changes from teacher-centered to students-centered (Novilia \& Iskandar, 2016).

Bilgin (2009) revealed that the guided inquiry learning model involved students in answering teacher questions. Students conducted investigations, while teachers guided students towards the right answers (Ifeoma \& Oge, 2013). The guided inquiry learning model requires the teacher to have skills in providing guidance, called diagnosing students' difficulties and giving students assistance in solving problems. Students must be able to design an experiment or research, analyze results, to make conclusions (Sukma \& Ibrahim, 2016). The learning process in guided inquiry includes five steps: formulating a problem, submitting a hypothesis, collecting data, testing hypotheses, and drawing conclusions (Banerjee, 2010).

The guided inquiry learning model aims to educate students to think logically, critically, rationally, and confidently in dealing with students' problems in the field of chemistry. Understanding, mastery of material and student learning outcomes were an indicator of the success of the chemical learning process. The higher the understanding and mastery of the material in students, the higher the learning outcomes were supported by the use of learning media.

Utilization of learning media at SMA Negeri 8 Semarang had not been maximized. The media used in the learning process in the form of student worksheets and chemical printed books for high schools were obtained in the library. The teacher used LCD only during a presentation by ppt. The teacher had not explained the video or illustration and did not use teaching aids as a medium to support learning. Learning media was a tool that 
carries messages to achieve learning goals (Rosadi, 2015). The use of learning media at SMA Negeri 8 Semarang must be improved and varied. Learning media could increase student motivation so that it influences the success of student learning outcomes along with teacher quality (Kapanadze, Bolte, Schneider, \& Slovinsky, 2015).

The most dominant factor in influencing learning success was teacher quality. The teacher must have a good attitude and personality, knowledge base in education according to the field of study, mastery of teaching techniques, and the ability to understand the minds of each student (Bartos \& Lederman, 2014). Sever \& Güven's (2014) study states that teachers act as motivators, facilitators, innovators, and conductors in handling problems faced by students. The teacher also acts as a mediator who had an important role in achieving learning goals and greatly determines the success of the educational process (Pérez, 2016). In addition, students also influence the learning process (Koksal \& Berberoglu, 2014). Each student had differences in intellectual abilities, physical abilities, family background, habits and relationships causing differences in the learning styles of each student (Azizmalayeri et al., 2012). Student learning difficulties were an obstacle in learning success, especially in chemistry subjects at SMA Negeri 8 Semarang. On this basis, the authors were interested in reviewing and analyzing the level of chemistry learning difficulties of students at SMA Negeri 8 Semarang to be able to improve their learning outcomes using the guided inquiry learning model.

\section{Conclusions}

Based on the results of observations at SMA Negeri 8 Semarang the students' learning outcomes in chemical materials were still low. Factors affecting the learning outcomes of chemistry in schools include three main components, they were the role of the teacher, learning material, and students. The interaction of the three components involves learning models, learning media, and learning environments. These factors greatly influence the success and learning outcomes of students in the learning process. One of the efforts to improve student learning outcomes in SMA Negeri 8 Semarang was by applying the guided inquiry learning model with accompanying learning media that are appropriate to students' interests. The guided inquiry learning model could make students more active in learning, so students could think critically, logically, and systematically in solving chemical problems. Further research is needed to determine the effect of the guided inquiry learning model assisted by learning media on students' chemistry learning outcomes at SMA Negeri 8 Semarang.

\section{References}

Azizmalayeri, K., Mirshahjafari, E., Sharif, M., Asgari, M., \& Omidi, M. (2012). The impact of guided inquiry methods on teaching critical thinking of high school students, 3(10), 42-48.

Banerjee, A. (2010). Teaching Science Using Guided Inquiry as the Central Theme: A Professional Development Model for High School Science Teachers, 1-10.

Bartos, SA, \& Lederman, NG (2014). Teachers' knowledge structures for nature of science and scientific inquiry: Conceptions and classroom practice. Journal of Research in Science Teaching, 51(9).

Bilgin, I. (2009). The effects of guided inquiry instruction incorporating a cooperative learning approach on university students' achievement of acid and basic concepts and attitudes toward guided inquiry instruction. Scientific Research and Essay, 4(10), 10381046.

Duran, M., \& Dökme, I. (2016). The effect of the inquiry-based learning approach on student's critical thinking skills. Eurasia Journal of Mathematics, Science and Technology Education, 12(12).

Gunawan, I. (2017). Indonesian Curriculum 2013: Instructional Management, Obstacles Faced by Teachers in Implementation and the Way Forward. 3rd International Conference on Education and Training. 
Gupta, T., Burke, KA, Mehta, A., \& Greenbowe, TJ (2015). Impact of guided-inquiry-based instruction with a writing and reflection emphasis on chemistry students' critical thinking abilities. Journal of Chemical Education, 92(1), 32-38.

Hunnicutt, SS, Grushow, A., \& Whitnell, R. (2015). Guided-inquiry experiments for physical chemistry: The POGIL-PCL model. Journal of Chemical Education, 92(2).

Ifeoma, OE, \& Oge, EK (2013). Effects of Guided Inquiry Method on Secondary School Students' Performance in Social Studies Curriculum in Anambra State, Nigeria, 3(3), 206-222.

Jack, GU (2013). Concept Mapping and Guided Inquiry as Effective Techniques for Difficult Teaching in Chemistry: Effect on Students' Academic Achievement. Journal of Education and Practice, 4(5), 9-16.

Kapanadze, M., Bolte, C., Schneider, V., \& Slovinsky, E. (2015). Enhancing science teachers' continuous professional development in the field of inquiry based science education. Journal of Baltic Science Education, 14(2).

Kimberlin, S., \& Yezierski, E. (2016). Effectiveness of Inquiry-Based Lessons Using Particulate Level Models to Develop High School Students' Understanding of Conceptual Stoichiometry. Journal of Chemical Education, 93(6).

Koksal, EA, \& Berberoglu, G. (2014). The Effect of Guided-Inquiry Instruction on 6th Grade Turkish Students' Achievement, Science Process Skills, and Attitudes Toward Science. International Journal of Science Education, 36(1).

$\mathrm{Ku}, \mathrm{KYL}$, Ho, IT, Hau, KT, \& Lai, ECM (2014). Integrating direct and inquirybased instruction in the teaching of critical thinking: an intervention study. Instructional Science, 42(2).

Muth'im, A. (2014). Understanding and Responding to the Change of Curriculum in the Context of Indonesian Education. American Journal of Educational Research.

Novilia, L., \& Iskandar, SM (2016). the Effectiveness of Colloid Module Based on Guided Inquiry Approach to Increase Students' Cognitive Learning Outcomes, 9(1), 17-23.

Pedaste, M., Mäeots, M., Siiman, LA, de Jong, T., van Riesen, SAN, Kamp, ET, ... Tsourlidaki, E. (2015). Phases of inquiry-based learning: Definitions and the inquiry cycle. Educational Research Review, 14, 47-61.

Pérez, CB (2016). What is a Scientific Experiment? The Impact of a Professional Development Course on Teachers' Ability to Design an Inquiry-Based Science Curriculum, 11(6), 1387-1401.

Rosadi, D. (2015). Interactive Learning Animation, 9(2), 132-137.

Roza, Y., Satria, G., \& Siregar, SN (2017). The Development of e-National Tutorial on Implementation 2013 for Mathematics Teachers. In Journal of Physics: Conference Series.

Setiawan, B., Sunarti, T., \& Astriani, D. (2016). The application of inquiry learning model to improve "One Roof" students' learning results at Singosari Middle School 4 Malang. Journal of Indonesian Science Education, 5(1), 45-50.

SEVER, D., \& GÜVEN, M. (2014). Effect of Inquiry-based Learning Approach on Student Resistance in a Science and Technology Course. Educational Sciences: Theory \& Practice, 14(4), 1601-1605.

Suárez,.., Specht, M., Prinsen, F., Kalz, M., \& Ternier, S. (2018). A review of the types of mobile activities in mobile inquiry-based learning. Computers and Education, 118.

Subandi. (2014). Indonesian Curriculum Development: Meaning-Based Curriculum and Competency-Based Curriculum in the 
Context of Teaching English Subject. In the Second International Conference on Education and Language (2nd ICEL) 2014.

Sukma, MC, \& Ibrahim, M. (2016). On campus topic on sense of hearing and sonar system of living organisms. Journal of Indonesian Science Education, 5(2), 256-260.

Susanto, EH (2014). The comparison between EFL textbook evaluations in 2013 curriculum and KTSP curriculum. In the 61 TEFLIN International Conference.

Ural, E. (2016) The Effect of Guided-Inquiry Laboratory Experiments on Science Education Students' Chemistry
Laboratory Attitudes, Anxiety and Achievement. Journal of Education and Training Studies, 4(4), 217-227.

Villagonzalo, EC (2014). Process oriented guided inquiry learning: An effective approach in enhancing students' academic performance. The DLSU Research Congress , (2009), 1-6.

Wardani, S., Nurhayati, S., \& Safitri, A. (2016). The Effectiveness of the Guided Inquiry Learning Module towards Students' Character and Concept Understanding. International Journal of Science and Research, 5(6), 15891594.

Zaini, M. (2016). Guided Inquiry Based Learning on the Concept of Ecosystem Towards Learning Outcomes and Critical Thinking Skills of High School Students, 6(6), 50-55. 